\title{
Correction: The role of salt abuse on risk for hypercalciuria
}

\author{
Patrícia Capuzzo Garcia Damasio ${ }^{1 *}$, Carmen Regina Petean Ruiz Amaro², Natália Baraldi Cunha ${ }^{3}$, \\ Ana Carla Pichutte ${ }^{3}$, José Goldberg ${ }^{4}$, Carlos Roberto Padovani ${ }^{5}$ and João Luiz Amaro ${ }^{4}$
}

\section{Correction}

Although the focus of our article in Nutrition Journal [1] reports some novel data and has a different focus compared to our publication in the International Brazilian Journal of Urology [2], we acknowledge that we have duplicated some text and results and that our Nutrition Journal article reports outcome data from the same study population. We have repeated some parts of the methods section from the International Brazilian Journal of Urology as well as the tables showing demographic characteristics and the biochemical characteristics of $24 \mathrm{hr}$ urine in the different study groups. Our data on salt intake regarding patients with urinary lithiasis and the related discussion are novel. We apologise for the inappropriate overlap between our two publications and our lack of transparency about the similarities between the two articles. Since publication of this article [1], it has come to our attention that there is an error in the section discussing assumptions about obesity-related costs. Table 2 is correct, indicating that $36 \%$ of the population is misidentified when BMI is considered, but there is a typographical error in the text which reported it as $31 \%$.

\begin{abstract}
Author details
${ }^{1}$ Graduate Student, Lithotripsy Service, Botucatu School of Medicine, UNESP, Botucatu, Brazil. ${ }^{2} \mathrm{PhD}$, Faculty at the Botucatu School of Medicine, UNESP, Lithotripsy Service, Botucatu, Brazil. ${ }^{3}$ Undergraduate Student, School of Nutrition, UNESP, Botucatu, Brazil. ${ }^{4}$ PhD, Faculty at the Botucatu School of Medicine, UNESP, Department of Urology, Botucatu, Brazil. ${ }^{5} \mathrm{PhD}$, Biosciences Institute, Department of Biostatistics, UNESP, Botucatu, Brazil.
\end{abstract}

Received: 16 May 2011 Accepted: 6 June 2011 Published: 6 June 2011

\section{References}

1. Damasio P, Amaro CR, Cunha NB, Pichutte AC, Goldberg J, Padovani CR, Amaro JL: The role of salt abuse on risk for hypercalciuria. Nutr J 2011, 10:3.

\footnotetext{
*Correspondence: pettysoft@uol.com.br

'Graduate Student, Lithotripsy Service, Botucatu School of Medicine, UNESP, Botucatu, Brazil

Full list of author information is available at the end of the article
}

2. Damasio P, Amaro CR, Berto SJ, Cunha NB, Pichutte AC, Padovani CR, Amaro JL: Urinary Lithiasis and Idiopathic Hypercalciuria: The Importance of Dietary Intake Evaluation. Int Braz J Urol 2010, 36(5):557-562.

\section{doi:10.1186/1475-2891-10-63}

Cite this article as: Damasio et al.: Correction: The role of salt abuse on risk for hypercalciuria. Nutrition Journal 2011 10:63.
Submit your next manuscript to BioMed Central and take full advantage of:

- Convenient online submission

- Thorough peer review

- No space constraints or color figure charges

- Immediate publication on acceptance

- Inclusion in PubMed, CAS, Scopus and Google Scholar

- Research which is freely available for redistribution

Submit your manuscript at www.biomedcentral.com/submit
( Biomed Central

\section{Biomed Central}

